Diabetologia 11, 93-100 (1975)

(C) by Springer-Verlag 1975

\title{
ORIGINALS
}

\section{Course and Prognosis of 86 Episodes of Diabetic Coma}

\author{
A Five Year Experience with a Uniform Schedule of Treatment
}

\author{
U. Keller, W. Berger, R. Ritz and P. Truog \\ Medical Department, University of Basle, Switzerland
}

Received: August 31, 1974, and in revised form: November 18, 1974

\begin{abstract}
Summary. The admission data and the course of 58 episodes of severe diabetic ketoacidotic coma and of 28 episodes of non-ketotic coma are compared. The non-ketotic patients were older; initial blood glucose, osmolarity, blood urea and serum sodium concentration were higher than in the ketotic patients. Treatment in the first $24 \mathrm{hrs}$ consisted of similar amounts of insulin in both coma forms, the presence of acidaemia did not increase the insulin needs. Acidaemia was corrected only when $\mathrm{pH}$ was below 7.20. The disadvantages of alkali therapy are emphasized. A comparison of the age groups of survivors and those patients who died within 72 hrs showed an increase in mortality with age. However, the mortality rates from ketotic and non-ketotic coma were simi-
\end{abstract}

lar in the age groups above 50 years. On admission, blood glucose, osmolarity and blood urea were higher in the fatal cases. Blood urea was the most important indicator of a fatal outcome. The response of blood glucose to insulin was impaired in the subsequently fatal cases. Insulin was given in "moderate" doses by constant infusion. The use of "small" doses is discussed. Early mortality was $14 \%$ in the ketotic and $29 \%$ in the non-ketotic cases. The most frequent causes of death were circulatory failure of undetermined origin, infections and thromboembolic complications.

Key words: Diabetic coma, ketoacidosis, non-ketotic hyperosmolar coma, acidosis, mortality, blood urea.
According to recent epidemiological studies diabetic coma occurs in 3 of 1,000 diabetics per year (Panzram, 1). The indicence will obviously depend on the proper education of both, doctor and patient. However, as the same author has pointed out, about $1 / 3$ of the cases were in patients not known previously to be diabetic, so that a certain incidence will always be maintained.

Diabetic coma is associated with a high mortality. We introduced in 1968 a schedule of treatment [2] which we hoped would be of benefit to hospital physicians for the rapid and safe correction of the metabolic disorder.

Therapeutic measures should include the immediate administration of insulin and the correction of fluid and electrolyte deficits although the amounts of the single components and their rate of administration remain controversial $[3,4]$.

The following study was performed first to prove the value of an easily manageable schedule of treatment; second, to provide a schedule for use in the treatment of both ketotic and non-ketotic hyperosmolar coma and to compare the course and features of these two syndromes, and third, to delineate useful prognostic factors for morbidity and mortality.

Previous observations on mortality of diabetic coma include cases of minor severity and treatment is not attempted according to a prospective program. Therefore, the risk factors for mortality are evaluated in patients with severe precoma and coma under comparable therapy.

\section{Material and Methods}

The case records of 58 consecutive episodes of ketotic and 28 episodes of non-ketotic coma in 75 patients were analyzed. All patients were treated in the Intensive Care Unit (ICU) of the Medical Clinic, University Hospital, Basle, in the years 1968-1973.

The depth of coma was evaluated in each case on admission and $12 \mathrm{hrs}$ after onset of therapy. The patients were allocated into 3 grades of unconsciousness. Patients in grade 1 on admission were awake and fully responsive, they were excluded from the study. Grade 2 included patients who reacted to external stimuli, they were not able to give adequate responses. Patients in grade 3 were comatose, voluntary motions upon external stimulation were absent.

Allocation to the group with ketoacidotic coma depended on a positive plasma acetone test [5], on the presence of acidaemia $(\mathrm{pH}<7.30)$ and on elevated blood glucose $(>350 \mathrm{mg} / 100 \mathrm{ml})$. Non-ketotic hyperosmolar coma was said to be present when 
plasma osmolality was greater than $330 \mathrm{mOsm} / \mathrm{kg}$ with a blood glucose concentration greater than 500 $\mathrm{mg} / 100 \mathrm{ml}$ and a negative plasma acetone test. Osmolality was calculated according to the formula:

$$
\begin{aligned}
& \mathrm{mOsm} / \mathrm{kg}=2(\mathrm{Na}+\mathrm{K})(\mathrm{mEq} / \mathrm{l})+ \\
& \frac{\text { glucose }(\mathrm{mg} / 100 \mathrm{ml})}{18}+\frac{\text { urea }(\mathrm{mg} / 100 \mathrm{ml})}{6}
\end{aligned}
$$

A semiquantitative guide to blood glucose and ketone body concentrations was obtained in the emergency room by using test strips (Tes Tape ${ }^{\circledR}$ and Ketostix $\left.^{\circledR}\right)$ on tear fluid [6]. This allowed early diagnosis and the immediate onset of treatment. The first insulin dose $(10-50 \mathrm{U})$ of regular insulin was given intravenously or intramuscularily according to the estimated or known blood glucose. Insulin was then administered by constant infusion. The rate of insulin infusion depended on the concentration of blood glucose and on the result of the plasma acetone test. $20-140 \mathrm{U}$ per $2 \mathrm{hrs}$ of insulin were administered in the presence of ketoacidosis and $10-100 \mathrm{U}$ per $2 \mathrm{hrs}$ in non-ketotic cases. Potassium therapy was begun only after knowledge of serum potassium. The amount of intravenous fluid was judged by the central venous pressure (CVP); the type of fluid depended on the serum sodium concentration. Acidaemia was corrected by sodium bicarbonate only when $\mathrm{pH}$ was below 7.20. The amount of bicarbonate given was calculated according to the formula: $\mathrm{mEq}=0.1 \times$ Base Excess $(\mathrm{BE}) \times$ Body wt. $(\mathrm{kg})$. Subsequent treatment with insulin, sodium, potassium and fluids was adjusted at two-hourly intervals according to the re- sults of biochemical monitoring. The dose of insulin depended on the rate of fall of blood glucose; on the basis of this the dose of the first infusion was repeated or reduced to as little as $1 / 8$. The details of the schedule of treatment have been published previously $[2,6]$.

Fatalities were divided into early (less than $72 \mathrm{hrs)}$ and late deaths (after $72 \mathrm{hrs}$ ). In the following results the survivors and the early deaths are compared.

Students t-test and the $\chi^{2}$-test were used for statistical analysis. All data are indicated as means \pm S.D.

\section{Results}

\section{Admission Data}

Age and Sex (Table 1). The mean age on admission was significantly higher for the cases with nonketotic coma (range $49-87$ years) as compared to those with ketotic coma (range 19-84 years).

A comparison of deaths with age showed the fatal cases to be older than non-fatal cases, the difference was statistically significant. Mortality rates in the various age groups are shown in Table 2 , the most significant finding being that only one death occurred under the age of 50 . The mortality rates of both forms of coma were similar in the decades from $50-89$ years.

The distribution of sex indicates a higher prevalence of diabetic coma in females, whereas mortality rate was greater in males.

Table 1. Age and sex

\begin{tabular}{lllllll}
\hline & $\begin{array}{l}\text { Ketotic } \\
\text { coma }\end{array}$ & $\begin{array}{l}\text { Non-ketotic } \\
\text { coma }\end{array}$ & Survivors & Deaths & $\mathrm{p}$ \\
\hline $\begin{array}{l}\text { Age (yrs.) } \\
\text { Sex and }\end{array}$ & $51 \pm 20$ & $70 \pm 10$ & $<0.001$ & $55 \pm 20$ & $66 \pm 11$ & $<0.05$ \\
$\begin{array}{l}\text { No. of cases } \\
\text { Total no. of cases }\end{array}$ & $23 \mathrm{~m} 35 \mathrm{f}$ & $12 \mathrm{~m} 16 \mathrm{f}$ & $26 \mathrm{~m} 44 \mathrm{f}$ & $9 \mathrm{~m} 7 \mathrm{f}$ & \\
\hline
\end{tabular}

\begin{tabular}{|c|c|c|c|c|c|}
\hline \multirow[t]{2}{*}{ Age } & \multicolumn{2}{|c|}{ Ketotic Coma } & \multicolumn{2}{|c|}{$\begin{array}{l}\text { Non-ketotic } \\
\text { Coma }\end{array}$} & \multirow[t]{2}{*}{$\begin{array}{l}\text { Mortality } \\
\text { All cases }\end{array}$} \\
\hline & $\begin{array}{l}\text { No. of } \\
\text { cases }\end{array}$ & $\begin{array}{l}\text { No. of } \\
\text { deaths }\end{array}$ & $\begin{array}{l}\text { No. of } \\
\text { cases }\end{array}$ & $\begin{array}{l}\text { No. of } \\
\text { deaths }\end{array}$ & \\
\hline $18-40$ yrs & 19 & 0 & 0 & 0 & $0 \%$ \\
\hline $40-49$ yrs & 7 & 1 & 1 & 0 & $13 \%$ \\
\hline $50-59$ yrs & 4 & 2 & 3 & 1 & $43 \%$ \\
\hline $60-69$ yrs & 19 & 2 & 13 & 4 & $19 \%$ \\
\hline $70-79$ yrs & 5 & 2 & 6 & 2 & $36 \%$ \\
\hline $80-89$ yrs & 4 & 1 & 5 & 1 & $22 \%$ \\
\hline
\end{tabular}

Table 2. Mortality and age
Laboratory Values on Admission. Non-ketotic coma was associated with significantly higher values of initial blood urea, osmolality and sodium in comparison with the ketotic cases (Table 3). Blood glucose was similar in both groups. The increased sodium and osmolality in the non-ketotic cases suggests a predominant deficit of free water in these cases.

Serum creatinine was erroneously high in ketoacidotic patients because acetoacetate interfered with creatinine measurement in our laboratory technique [8]. 
Blood urea, osmolality and blood glucose were significantly elevated in patients who subsequently died. Sodium and potassium concentration were similar in both groups. Since a high blood urea and osmolality were both associated with a high mortality, we tried to elucidate the differential contribution of these two interrelated factors (Table 4). As a result of this analysis it appeared that a raised blood urea was associated with a high mortality irrespective of serum osmolality.
One can therefore postulate that the degree of depletion was the same in the two groups of patients. However, more rapid administration was necessary in the initial period in the ketotic patients reflecting no doubt the effects of correction of acidaemia. In non-ketotic coma, the hourly potassium administration did not exceed $50 \mathrm{mEq}$ per hour, whereas in ketotic patients amounts of $60-100 \mathrm{mEq}$ per hour were sometimes needed to correct hypokalemia.

Both groups of patients were given similar amounts

Table 3. Laboratory values on admission

\begin{tabular}{|c|c|c|c|c|c|c|}
\hline & Ketotic Coma & $\begin{array}{l}\text { Non-ketotic } \\
\text { Coma }\end{array}$ & $\mathrm{p}$ & Survivors & Deaths & $\mathrm{p}$ \\
\hline Glucose $(\mathrm{mg} / 100 \mathrm{ml})$ & $861 \pm 287$ & $931 \pm 298$ & n.s. & $845 \pm 273$ & $1051 \pm 315$ & $<0.02$ \\
\hline Sodium $(\mathrm{mEq} / \mathrm{l})$ & $135 \pm 12$ & $144 \pm 15$ & $<0.01$ & $137 \pm 14$ & $140 \pm 11$ & n.s. \\
\hline Osmolality (mOsm/kg) & $350 \pm 34$ & $372 \pm 27$ & $<0.001$ & $352 \pm 32$ & $378 \pm 34$ & $<0.01$ \\
\hline Urea $(\mathrm{mg} / 100 \mathrm{ml})$ & $111 \pm 60$ & $152 \pm 63$ & $<0.005$ & $112 \pm 60$ & $170 \pm 48$ & $<0.001$ \\
\hline Potassium $(\mathrm{mEq} / 1)$ & $5.0 \pm 1.3$ & $4.4 \pm 1.3$ & n.s. & $4.8 \pm$ & $4.8 \pm$ & n.s. \\
\hline $\mathrm{pH}$ & $7.0 \pm 0.2$ & $7.3 \pm 0.3$ & $<0.001$ & $7.1 \pm 0.2$ & $7.1 \pm \quad 1.7$ & n.s. \\
\hline
\end{tabular}

Table 4. Initial blood urea, osmolality and mortality

\begin{tabular}{cccc}
\hline & $\begin{array}{l}\text { Survivors } \\
\text { No. of cases }\end{array}$ & $\begin{array}{l}\text { Deaths } \\
\text { No. of cases }\end{array}$ & Mortality \\
\hline Blood Urea $<150 \mathrm{mg} / 100 \mathrm{ml}$ & & & $7 \%$ \\
Osm $<370 \mathrm{mOsm} / \mathrm{kg}$ & 42 & 3 & $7 \%$ \\
Osm $>370 \mathrm{mOsm} / \mathrm{kg}$ & 13 & 1 & $50 \%$ \\
Blood Urea $>150 \mathrm{mg} / 100 \mathrm{ml}$ & & & $43 \%$ \\
Osm $<370 \mathrm{mOsm} / \mathrm{kg}$ & 3 & 3 & $19 \%$ \\
Osm $>370 \mathrm{mOsm} / \mathrm{kg}$ & 12 & 9 & 16 \\
Total No. of Cases & 70 & 16 & \\
\hline
\end{tabular}

Table 5. Treatment in the initial $24 \mathrm{hrs}$

\begin{tabular}{|c|c|c|c|c|c|c|}
\hline & $\begin{array}{l}\text { Ketotic Coma } \\
\mathrm{n}=58\end{array}$ & $\begin{array}{l}\text { Non-ketotic C. } \\
\mathrm{n}=28\end{array}$ & $\mathrm{p}$ & $\begin{array}{l}\text { Survivors } \\
\mathrm{n}=70\end{array}$ & $\begin{array}{l}\text { Deaths } \\
n=16\end{array}$ & $\mathrm{p}$ \\
\hline Insulin (U) & $344 \pm 233$ & $288 \pm 204$ & n.s. & $313 \pm 212$ & $507 \pm 292$ & $<0.02$ \\
\hline Potassium (mEq) & $216 \pm 94$ & $193 \pm 111$ & n.s. & $219 \pm 98$ & $171 \pm 101$ & n.s. \\
\hline $\begin{array}{l}\text { Maximal Potassium Ad- } \\
\text { ministration per hour (mEq) }\end{array}$ & $37 \pm 18$ & & & & & \\
\hline Total Fluids (1) & $8.0 \pm 2.7$ & $8.4 \pm \quad 3.4$ & n.s. & $8.2 \pm \quad 2.9$ & $\begin{aligned} 29 & \pm \\
7.9 \pm & \end{aligned}$ & $\begin{array}{l}\text { n.s. } \\
\text { n.s. }\end{array}$ \\
\hline $\begin{array}{l}\text { Positive Balance (1) } \\
\text { (Fluids minus Urine) }\end{array}$ & $5.4 \pm \quad 2.5$ & $6.8 \pm 3.1$ & $<0.02$ & $5.6 \pm \quad 2.7$ & $7.2 \pm \quad 4.0$ & n.s. \\
\hline Sodium (mEq) & $771 \pm 337$ & $528 \pm 346$ & $<0.01$ & $689 \pm 351$ & $805 \pm 341$ & n.s. \\
\hline Bicarbonate (mEq) & $345 \pm 238$ & $157 \pm 148$ & $<0.001$ & $267 \pm 238$ & $337 \pm 220$ & n.s. \\
\hline
\end{tabular}

\section{Treatment in the First 24 Hours (Table 5)}

On average the ketotic patients were given slightly more insulin than the non-ketotic cases, but the difference was not significant.

The amount of potassium required in the first 24 hrs was similar in the ketotic and non-ketotic cases. of fluid but the non-ketotic patients retained significantly more fluid, and were also given significantly less sodium. The latter reflects the practice of administrating hypotonic fluids to the non-ketotic patients.

Obviously ketotic patients received more bicarbonate than the non-ketotic group. Lactic acidaemia 
( $\mathrm{pH}<7.25)$ was found to be present in $2(10 \%)$ of the surviving and in $6(75 \%)$ of the dying non-ketotic patients. This required rigorous alkali therapy which explains why the non-ketotic groups as a whole was given considerable amounts of bicarbonate.

When the treatment of the survivors and the nonsurvivors is compared, the amount of insulin given was the only parameter with a significant difference. Seven patients with a survival time of less than 24 hrs were excluded from the calculation. Less potassium and more bicarbonate was administered to the patients who died because of the frequent incidence of shock. each instance, and no patient was lost from hypokalemia. Increased serum potassium $(>6.0 \mathrm{mEq} / \mathrm{l})$ was seen in $6(37 \%)$ of the dying patients. In these cases hyperkalemia was associated with shock or anuria.

The central venous pressure (CVP) on admission showed a broad range from -2 to $15 \mathrm{~cm} \mathrm{H}_{2} \mathrm{O}$. The average minimal CVP observed during the first 24 hours was lower in the ketotic than in the non-ketotic cases (Table 6). It is particularly noteworthy that maximal and minimal CVP readings were significantly greater in the fatal cases compared with the survivors. Hypotensive episodes in the first 24 hours

Table 6. Course in the initial 24 hrs

\begin{tabular}{|c|c|c|c|c|c|c|}
\hline & Ketotic Coma & Non-ketotic C. & $\mathrm{p}$ & Survivors & Deaths & $\mathrm{p}$ \\
\hline \multicolumn{7}{|l|}{ Time to decline of BS below } \\
\hline $300 \mathrm{mg} / 100 \mathrm{ml}(\mathrm{hrs})$ & $8.7 \pm 3.7$ & $10.3 \pm 5.1$ & n.s. & $8.8 \pm 4.0$ & $12.1 \pm 5.1$ & $<0.05$ \\
\hline $\mathrm{n}=$ & 57 & 26 & & 70 & 13 & \\
\hline Minimal CVP $\left(\mathrm{cm} \mathrm{H}_{2} \mathrm{O}\right)$ & $1.4 \pm 2.9$ & $3.2 \pm 4.2$ & $<0.02$ & $1.5 \pm 3.0$ & $4.3 \pm 4.5$ & $<0.02$ \\
\hline $\mathrm{n}=$ & 49 & 25 & & 62 & 12 & \\
\hline Maximal CVP $\left(\mathrm{cm} \mathrm{H}_{2} \mathrm{O}\right)$ & $11.3 \pm 3.5$ & $11.4 \pm 5.0$ & n.s. & $10.9 \pm 3.3$ & $13.6 \pm 6.2$ & $<0.05$ \\
\hline $\mathrm{n}=$ & 49 & 25 & & 62 & 12 & \\
\hline \multicolumn{7}{|l|}{ No. of hypotensive Episodes } \\
\hline$(\mathrm{BP}<80 \mathrm{~mm} \mathrm{Hg})$ & 19 & 9 & n.s. & 14 & 14 & $<0.001$ \\
\hline $\mathrm{n}=$ & 55 & 26 & & 66 & 15 & \\
\hline
\end{tabular}

Table 7. Consciousness $12 \mathrm{hrs}$ after admission in survivors and deaths of ketotic (KC) and non-ketotic (NC) coma

\begin{tabular}{lllll}
\hline & $\begin{array}{l}\text { Grade 1 } \\
\text { No. of cases }\end{array}$ & $\begin{array}{l}\text { Grade 2 } \\
\text { No. of cases }\end{array}$ & $\begin{array}{l}\text { Grade 3 } \\
\text { No. of cases }\end{array}$ & $\begin{array}{l}\text { Total } \\
\text { No. of cases }\end{array}$ \\
\hline Survivors (KC) & 38 & 11 & 1 & 50 \\
Deaths (KC) & 0 & 4 & 3 & 7 \\
KC (all cases) & $38(67 \%)$ & $15(26 \%)$ & $4(7 \%)$ & $57(100 \%)$ \\
Survivors (NC) & 9 & 6 & 2 & 17 \\
Deaths (NC) & 0 & 1 & 4 & 5 \\
NC (all cases) & $9(41 \%)$ & $7(32 \%)$ & $6(27 \%)$ & $22(100 \%)$ \\
\hline
\end{tabular}

\section{Course in the First 24 Hours (Table 6)}

Blood glucose fell below $300 \mathrm{mg} / 100 \mathrm{ml}$ after a mean duration of $8.7 \mathrm{hrs}$ in the ketotic cases as compared to $10.3 \mathrm{hrs}$ in the non-ketotic patients. Blood glucose values below $80 \mathrm{mg} / 100 \mathrm{ml}$ were present in $11(19 \%)$ of the ketotic cases after a mean interval of $17 \mathrm{hrs}$, whereas no decline below this level occurred in the non-ketotic patients. Therefore, in ketotic coma insulin sensitivity is rapidly restored.

The decline of blood glucose was significantly slower in dying patients compared with survivors.

Hypokalemia $(<3.0 \mathrm{mEq} / \mathrm{l})$ was observed in 18 (23\%) of all patients after a mean duration of $4.9 \mathrm{hrs}$. Rapid correction of serum potassium was possible in were observed in 28 cases. The occurence of hypotension was an ominous sign, 14 (93\%) of the nonsurvivors compared to $14(21 \%)$ of the survivors were hypotensive or were in established shock. This explains the occurence of lower urine outputs in the fatal cases.

Consciousness. The degree of unconsciousness was evaluated in each case on admission and $12 \mathrm{hrs}$ after onset of treatment. On admission, 33 of the cases were classified as grade 2 representing the group of "pre" coma, whereas 52 patients were in grade 3 , they were in deep coma. The depth of coma on admission did not correlate with either the extent of the acidaemia or mortality. In contrast, there was a marked correlation between the impairment of consciousness 12 
hrs after admission and subsequent outcome (Table 7). Prolonged coma was typical of the fatal cases while non-ketotic patients recovered more slowly than ketotic ones.

\section{Pathologic Findings in the Deaths}

The mortality rates in the ketotic and in the nonketotic cases are summarized in Table 8. Two thirds

Table 8. Mortality

\begin{tabular}{|c|c|c|c|}
\hline & $\begin{array}{l}\text { Ketotic } \\
\text { coma } \\
\mathrm{n}=58\end{array}$ & $\begin{array}{l}\text { Non- } \\
\text { ketotic } \\
\text { coma } \\
\mathrm{n}=28\end{array}$ & $\begin{array}{l}\text { All } \\
\text { comas } \\
\mathrm{n}=86\end{array}$ \\
\hline \multicolumn{4}{|l|}{ No. of deaths within } \\
\hline $72 \mathrm{hrs}$ & 8 & 8 & 16 \\
\hline early mortality & $14 \%$ & $29 \%$ & $19 \%$ \\
\hline $\begin{array}{l}\text { No. of deaths after } \\
72 \mathrm{hrs}\end{array}$ & 5 & 3 & 8 \\
\hline late mortality & $9 \%$ & $11 \%$ & $9 \%$ \\
\hline No. of all deaths & 13 & 11 & 24 \\
\hline total Mortality & $22 \%$ & $39 \%$ & $28 \%$ \\
\hline
\end{tabular}

Table 9

\begin{tabular}{lll}
\hline \multicolumn{3}{c}{ Causes of early deaths } \\
\hline & Ketotic & Non-ketotic \\
& coma & coma \\
& $\mathrm{n}=8$ & $\mathrm{n}=8$ \\
Circulatory failure & 4 & 2 \\
Pneumonia & 1 & 2 \\
Pulmonary embolism & 1 & 2 \\
Intestinal bleeding & 1 & 1 \\
Brain edema & 1 & 0 \\
Cerebrovasc. accident & 0 & 1 \\
\hline & & \\
\hline & Causes of late deaths \\
& Ketotic & Non-ketotic \\
& coma & coma \\
& $\mathrm{n}=5$ & $\mathrm{n}=3$ \\
& 1 & 1 \\
Malignancy & 2 & 0 \\
Cirrhosis of liver & 1 & 1 \\
Pneumonia & 1 & 0 \\
Pulmonary embolism & 0 & 1 \\
Unknown & & \\
\hline
\end{tabular}

of the deaths occurred within 3 days, one third later during the same hospitalisation. The mortality rate of non-ketotic coma seemed to be higher than that of ketotic coma.

Table 9 describes the causes of the early and of the late deaths. Postmortem examination was performed in all cases except one (cause of death unknown). In 7 cases of early death the fatal outcome was attrib- uted to severe diabetic coma. In 6 of them final diagnosis was circulatory failure. In each case, chronic heart disease was found (ischaemic heart disease in 5, hypertensive heart disease in one). Their course was characterized by protracted hypotension despite adequate fluid therapy. In one case severe brain edema was diagnosed (brain weight $1590 \mathrm{~g}$ ); however, this patient underwent open cardiac massage for a prolonged period of time. The case was associated with severe ketoacidosis.

The eight cases of late death occurred 6-65 days following recovery from coma. In most of them chronic illnesses with no relation to the preceding coma was the cause of death. Therefore it seems to be justified to ascribe mortality of diabetic coma to a limited interval after onset of treatment.

\section{Discussion}

Each case of diabetic coma is an emergency situation which requires rapid and adequate treatment [11]. Since mortality is still high and since one third of the patients of our and of reported series $[12,13]$ died as a consequence of the metabolic derangement, improved treatment should ameliorate the prognosis of diabetic coma.

Controversy surrounds the administration of insulin. Our patients received amounts in the first 24 hrs similar to those reported elsewhere (review in 14). In a recent publication Alberti et al. [3] renewed the discussion about the optimal insulin therapy in proposing an intramuscular regimen of low doses of insulin. Further studies $[15,16,17]$ advocated the administration of similar doses by constant infusion. These results are in accord with previous studies [18] that in the majority of cases smaller doses than generally recommended [14] are effective as large doses. It is possible that in many cases an unsatisfactory hypoglycaemic response to insulin cannot be overcome by increasing the insulin dose, and the restoration of sensitivity to insulin is the conditio sine qua non for the blood glucose lowering effect of insulin.

However, the average degree of severity of these reported "coma" patients was less than that of our cases when the initial blood glucose and the degree of coma are compared. In our fatal episodes blood glucose fell significantly slower than in the surviving patients in spite of the larger amounts of insulin given. Thus, the capability of insulin to lower blood glucose was impaired and the insulin requirements in those who died may have been higher. In clinical practice it is impossible to predict the response to a certain amount of insulin in a coma patient, and it may be that "small" insulin doses aimed at producing serum 
insulin concentrations that saturate insulin receptors, are sometimes too low. Therefore, we consider it not yet advisable to recommend generally the use of "small" doses because they may fail to meet the insulin requirements of an individual patient.

As to the way of administration, we continue to give insulin by constant infusion. By this route, treatment is easier to control, and the risk of late hypoglycemia should be less than with intramuscular therapy. Furthermore, we do not know in the severe cases with circulatory problems if adsorption of insulin at the injection site is adequate. In contrast to the finding of Sönksen [19] who examined minimal amounts of insulin, the absorption of currently used amounts of insulin to glass and plastic tubes should not be of major importance for the patient $[15,20]$.

The observation that non-ketotic patients seemed to need similar amounts of insulin to the ketotic cases confirms previous statements $[21,22]$ that insulin sensitivity was rapidly restored after initiation of therapy. The same statement can be made on the patients reported by Walker [24]. He demonstrated that in the initial period of acidaemia the hypoglycaemic effect of insulin was impaired, but his interpretion that impaired insulin action was caused by acidaemia is not conclusive.

The recovery of insulin sensitivity which is more rapid in ketotic cases leads to a rapid decline of blood glucose. This emphasizes the need for frequent monitoring of blood glucose and for changing intravenous therapy to a glucose infusion when blood glucose falls below $300 \mathrm{mg} / 100 \mathrm{ml}$.

Potassium supplementation requires close attention since rapid changes of serum potassium are the rule. Hypokalemia occurred as frequently as hyperkalemia, therefore, the application of the schedule roughly guaranteed the correct estimation of the potassium needs. Hypokalemia developed in most cases in the early hours of treatment, therefore insulin and alkali treatment without rapid institution of potassium supply is hazardous. Potassium supply should be curtailed in the absence of good urine output.

The amount of potassium required to correct hypokalemia was in keeping with previous reports $[4,9]$ that patients with diabetic coma often are in a state of potassium depletion previously underestimated. It demonstrates that earlier recommendations $[10,25]$ regarding limited potassium repletion are hazardous. According to recent studies the risk of hypokalemia should be attenuated by the use of "small" doses of insulin $[3,15,17]$.

Since hypotension and oliguria were a frequent complication, the monitoring of CVP was a prere- quisite for adequate fluid therapy. By this way, liberal amounts of fluid were given. Subsequent complications such as peripheral or pulmonary edema were not observed. Hypotension should primarily be treated with fluid, since fluid deficit is its major cause. The administration of plasma should be limited to cases who fail to respond to fluid therapy. The observation that protracted hypotension in the fatal cases was associated with raised CVP-readings infers that the problem was primarily one of depressed cardiac activity. Protracted renal failure is a known complication of hypotension in diabetic coma [26], and it was felt that absence of such cases was due to the vigorous fluid administration. The sodium concentration in the infused fluids was adjusted according to the serum sodium. Through this means the separate appraisal of sodium and water needs of ketotic and non-ketotic coma was satisfied.

The institution of therapy leads to shifts of water into the cells, therefore serum sodium concentration tends to rise. In cases where serum sodium is above $145 \mathrm{mEq} / 1$ we recommend the use of hypotonic solutions.

In the light of recent studies concerning alkali therapy in metabolic acidaemia [27] the question arose as to whether alkalinisation has unfavorable effects mediated by a leftshift of the oxyhemoglobin dissociation curve (Bohr effect). In diabetic acidaemia this effect is of special importance because of marked and prolonged decrease of red blood cell 2, 3 - disphosphoglycerate [28]. This causes an increase in oxygen affinity of hemoglobin which may lead to tissue hypoxia. Further unfavorable effects of alkali therapy are the subsequent potassium shifts into the cells which augments the risk of hypokalemia, and the decrease of the venular tone following alkalinization [29]. This latter effect may be responsible for the clinical observation of a decrease of CVP and blood pressure after onset of treatment of diabetic acidaemia. However, treatment of metabolic acidaemia is considered to be mandatory because severe acidaemia impairs cardiac function [30]. Alkali therapy is indicated only when $\mathrm{pH}$ falls below a critical level (e.g. 7,10 ).

The evaluation of the risk factors of diabetic coma indicated that elevation of blood urea, osmolality and blood glucose on admission were associated with fatality. Similar observations have been made before $[11,13,31]$. In addition, our data demonstrate that initial blood urea was the most important prognostic factor. An evaluation of blood urea versus osmolality indicated that osmolality per se was not associated with mortality. The increased level of blood urea may be due to increased production and to lowered renal 
elimination of urea. Thus it reflects the amount and duration of catabolism and the impairment of renal function brought about by dehydration and increased blood viscosity [32]. The mean age of the patients who died was significantly higher than that of the survivors, however, the mortality rates of both coma forms in the age groups above 50 years were similar. Hence it is concluded that prognosis of diabetic coma is not worse in extreme old age than in late middle age, therefore, intensive treatment should be stressed even in elderly patients.

Other factors associated with mortality were prolonged duration of coma and circulatory failure. As previously reported $[12,13]$, a large number of patients who died subsequent to diabetic coma were in cardiac failure resistant to therapy.

Associated conditions were present in the majority of cases the most frequent being infection. As a precipitating factor of diabetic coma early recognition and treatment of infection is important. Furthermore, the course of treatment is aggravated by the presence of infection. Blood glucose tends to fall more slowly in these cases [3] since anti-insulin hormones such as glucagon are higher in infected than non-infected cases [33].

Complications with thromboembolic disorders were responsible for $1 / 4$ of our fatalities. In a recent report on fatal diabetic ketoacidosis [34] cerebral intravascular coagulation was implicated as cause of death. One should at least consider the use of prophylactic anticoagulants. However, in view of the high incidence of erosive gastritis and gastrointestinal bleeding early prophylactic anticoagulation is probably contraindicated.

The development of brain edema seemed to be of minor importance as cause of death. This confirms the statement of Beigelman [13] that it is not justified to accuse aggressive treatment for this fatal complication [36].

Our mortality rates are higher than that of other reports $[11,12,35]$, however, only severe cases have been studied. They demonstrate that the metabolic derangement and the complications of diabetic coma are still a challenge to any practicing physician.

Acknowledgements. The results of the pathologic examinations were provided by courtesy of Prof. H. U. Zollinger. We thank Prof. K. G. M. M. Alberti, Southampton, for critical review of the manuscript.

\section{References}

1. Panzram, G.: Epidemiologie des Coma diabeticum. Schweiz. med. Wschr. 103, 203-208 (1973)

2. Berger, W., Affolter, H., Kapp, H.: Diagnose und Behandlung der diabetischen Ketoazidose und Hyperosmolarität. Praxis 58, 1096-1103 (1969)
3. Alberti, K. G. M. M., Hockaday, T. D. R., Turner, R. C.: Small doses of intramuscular insulin in the treatment of diabetic coma. Lancet 1973 II, $515-522$

4. Soler, N. G., Bennett, M. A., Dixon, K., FitzGerald, M. G., Malins, J. M.: Potassium balance during treatment of diabetic ketoacidosis, with special reference to the use of bicarbonate. Lancet 1972 II, 665-667

5. Bradley, R. F.: Treatment of diabetic ketoacidosis and coma. Med. Clin. N. Amer. 49, 972-986 (1965)

6. Berger, W.: Diagnose und Behandlung diabetischer Notfallsituationen in der Praxis und im Spital. Schweiz. med. Wschr. 102, 1008-1016 (1972)

7. Daughaday, W. M., Lipicky, R. S., Rasinski, D. C.: Lactic acidosis as a cause of acidosis in diabetic patients. New Engl. J. Med. 267, 1010-1014 (1962)

8. Watkins, P. J.: The effect of ketone bodies on the determination of creatinine. Clin. chim. Acta 18, 191-196 (1967)

9. Seftel, H. C., Kew, M. C.: Early and Intensive Potassium replacement in Diabetic Acidosis. Diabetes 15, 694-696 (1966)

10. Johnson, R. D.: Management of diabetic ketoacidosis. Postgrad. Med. 39, 246-256 (1966)

11. Soler, N. G., Fitzgerald, M. G., Bennett, M. A., Malins, J. M.: Intensive care in the management of diabetic ketoacidosis. Lancet 1973 I, 951-954

12. Assan, R., Aubert, Ph., Souchal, B., Tchobroutsky, G., Derot, M.: Analyse de 154 cas d'acidocétoses graves chez des diabétiques (1963-1967). Presse Méd. 77, 423-426 (1969)

13. Beigelman, P. M.: Severe diabetic ketoacidosis (Diabetic "Coma"). Diabetes 20, 490-500 (1971)

14. Bradley, R. F.: Diabetic ketoacidosis and coma. In: Joslin's Diabetes mellitus, p. 363. (Eds.: Marble, A., White, P., Bradley, R. F., Krall, L. P.) Philadelphia: Lea and Febiger 1971

15. Page M. Mc. B., Alberti, K. G. M. M., Greenwood, R., Gumaa, K. A., Hockaday, T. D. R., Lowy, C., Nabarro, J. D. N., Pyke, D. A., Sönksen, P. H., Watkins, P. J., West, T. E. T.: Treatment of diabetic coma with continuous low-dose infusion of insulin. Brit. med. J. 1974 II, 687690

16. Kidson, W., Casey, J., Kraegen, E., Lazarus, L.: Treatment of severe diabetes mellitus by insulin infusion. Brit. med. J. 1974 II, 691-694

17. Semple, P. F., White, C., Manderson, W. G.: Continuous intravenous infusion of small doses of insulin in treatment of diabetic ketoacidosis. Brit. med. J. 1974 II, 694698

18. Menzel, R., Jutzi, E.: Zum Blutzuckerverhalten bei Rekompensation des Coma diabeticum. Dtsch. Gesundh.Wes. 27, 727-732 (1970)

19. Sönksen, P. H., Ellis, J. P., Lowy, C., Rutherford, A., Nabarro, J. D. N.: A quantitative evaluation of the relative efficiency of gelatine and albumin in preventing insulin absorption to glass. Diabetologia 1, 208-210 (1965)

20. Völlm, K.: Über die Haltbarkeit von Insulin in physiologischen Natriumbicarbonatlösungen. Schweiz. med. Wschr. 90, 1080-1083 (1960)

21. Collins, J. V., Harris, P. W. R.: Non-keto-acidotic diabetic Coma. Postgrad. med. J., June Suppl. 47, 388-398 (1971)

22. Hockaday, T. D. R., Alberti, K. G. M. M.: Diabetic coma. Clin. Endocr. Metab. 1, 751-787 (1972)

23. Gerich, J. E., Martin, M. M., Recant, L.: Clinical and 
metabolic characteristics of hyperosmolar nonketotic coma. Diabetes 20, 228-238 (1971)

24. Walker, B. G., Phear, D. N., Martin, F. I. R., Baird, C. W.: Inhibition of insulin by acidosis. Lancet 1963 II, 964-965

25. Gwinup, G. G., Steinberg, T.: The management of diabetic coma, Calif. Med. 3, 347-350 (1969)

26. Bernstein, L. M., Folea, E. F., Hoffmann, W. S.: Renal function during and after diabetic coma. J. clin. Invest. 32, 711-716(1952)

27. Bellingham, A. J., Detter, J. C., Lenfant, C.: Regulatory mechanisms of hemoglobin oxygen affinity in acidosis and alkalosis. J. clin. Invest. 50, 700-706 (1971)

28. Alberti, K. G. M. M., Darley, J. H., Emerson, P. M., Hockaday, T. D. R.: 2,3-Disphosphoglycerate and tissue oxygenation in uncontrolled diabetes mellitus. Lancet 1972 II, 391-395

29. Harvey, R. M., Enson, Y., Lewis, M. L.: Hemodynamic effects of dehydration and metabolic acidosis in asiatic cholera. Trans. Ass. Amer. Phycns 79, 177-186 (1966)

30. Ng, M. L., Levy, M. N., Zieske, H. A.: Effects of changes of $\mathrm{pH}$ and of carbon dioxide tension on left ventricular performance. Amer. J. Physiol. 213 (1), 115-120 (1967)

31. Rabinowitch, I. M., Fowler, A. F., Bensley, E. H.: Diabetic coma (an investigation of mortalities and reports of a severity index for comparative studies). Ann. Int. Med. 12. $1403-1428$ (1939)

32. Reubi, F. C.: Glomerular function rate, renal blood flow and blood viscosity during and after diabetic coma. Circulat. Res. 1, 410-413 (1953)

33. Rocha, D. M., Santeusanio, F., Faloona, G. R.: Abnormal pancreatic alpha-cell function in bacterial infections. New Engl. J. Med. 288, 700-703 (1973)

34. Timperley, W. R., Preston, F. E., Ward, J. D.: Cerebral intravascular coagulation in diabetic ketoacidosis. Lancet 1974 I, 952-956

35. Beigelman, P. M., Warner, N. E.: Thirty-two fatal cases of severe diabetic ketoacidosis, including a case of mucormycosis. Diabetes 22, 847-850 (1973)

36. Hayes, T. M., Woods, C. J.: Unexpected death during treatment of uncomplicated diabetic ketoacidosis. Brit. med. J. 1968 IV, 32-33

Dr. U. Keller Kantonsspital Basel Dept. für Innere Medizin 1. Medizinische Univ.-Klinik CH-4004 Basel Switzerland 